\title{
Preliminary physicochemical assessment of groundwater in Kg. Salang, Pulau Tioman, Pahang, Malaysia
}

\begin{abstract}
Fourteen groundwater samples were collected from Kg. Salang in the north-west of Pulau Tioman, Pahang and were analysed for their physicochemical characteristics. The physicochemical parameters were analysed to know the present groundwater quality as well as the possible source of ions in the groundwater. The groundwater in the study area is fresh and the dominant water type is Caï Mgï HCO3. The occurrence of these facies is identified to be natural due the calcite of corals and shells. The statistical analysis shows strong correlation between Caï EC. Results concluded that the parameters which were taken for the study of water quality are below the pollution level for groundwater which satisfy the requirement for the use of various purposes like domestic, agricultural, and industrial.
\end{abstract}

Keyword: Groundwater; Physicochemical; Ions; Facies; Corals 